\title{
A bio- and chemostratigraphic search for the Mid-Ludfordian Carbon Isotope Excursion interval in the Ludlow of the Ohesaare core, Estonia
}

\author{
Dimitri Kaljo, Tõnu Martma, Tiiu Märss, Viiu-Kai Nestor and Viive Viira \\ Department of Geology, School of Science, Tallinn University of Technology, Ehitajate tee 5, 19086 Tallinn, Estonia; dimitri.kaljo@taltech.ee
}

Received 1 December 2021, accepted 2 February 2022, available online 1 March 2022

\begin{abstract}
For years, the Ohesaare core section and its rich fossil assemblages have enticed researchers to suggest various ideas about Silurian stratigraphy in the East Baltic despite several sedimentary gaps occurring through the Ludlow interval in particular. One of the gaps has removed from the Ohesaare record the most important event in the Palaeozoic history of carbon isotopes - the MidLudfordian Carbon Isotope Excursion (MLCIE), which is partly accompanied by the Lau biotic and oceanic events. In our research, we have performed a detailed distribution analysis of chitinozoans, conodonts, ostracodes and vertebrate microremains with the aim of documenting the evidence regarding the levels of certain environmental events largely preceding the MLCIE. For this purpose, the Torgu Formation was subdivided into five working units. The first results indicate a gap within the uppermost part of the Torgu Formation as a possible level for the missing MLCIE. In order to verify this, we compared the fossil distribution pattern in Ohesaare with that on Gotland (Sweden) and in Kurzeme (Latvia), including $\delta^{13} \mathrm{C}$ data from the Uddvide (Gotland) and Ventspils (Latvia) core sections. Both Baltic and Bohemian data show rather unanimously that the MLCIE is located below the Ozarkodina crispa conodont Biozone. However, some reports from Gotland show peak values also in higher strata; occasional records of $\mathrm{Oz}$. crispa from other places may cast some doubt on these findings and raise some ecostratigraphical concerns when discussing upper Ludfordian correlation.
\end{abstract}

Key words: microfossil, carbon isotope, Ludlow, Ohesaare core, Baltica.

\section{INTRODUCTION}

The Ohesaare core, in the southwestern corner of Saaremaa Island, Estonia (Fig. 1), was drilled in 19611962 by a team from the former Institute of Geology, Estonian Academy of Sciences, in order to uncover a deeper-water sedimentary facies and study as continuous as possible a succession of the Ordovician and Silurian rocks in the region. The first aim was distinctly accomplished when the first metres of the Monograptus riccartonensis Biozone graptolite-bearing bed were stored in core boxes. However, the continuity of the rocks needed more attention. After preliminary description of the Silurian section (Aaloe \& Kaljo 1962), the core became the object of diverse research: lithological and geochemical research (Aaloe \& Jürgenson 1977; Jürgenson 1988), facies models (Nestor \& Einasto 1977) and, perhaps most importantly, detailed palaeontological and biostratigraphical studies of various fossils serving as groundwork for the current paper. Below, we will discuss the results on ostracodes (Sarv 1968, 1971), vertebrates
(Märss 1986), chitinozoans (Nestor 2007, 2009) and conodonts (Viira 1999). Because of these and many other papers describing macrofossils, the Ohesaare core obtained a central position in the research history of the Baltic Silurian. This might also help to understand the slightly unusual title of the paper. In the course of the investigations, we rather soon understood that the section was not as continuous as we had expected; smaller or larger gaps occurred at several levels especially within the Ludlow (at the bottom of the Gorstian, but also higher, in the Ludfordian). On the other hand, based on the results of the analyses, we became convinced that not all of the missing records of fossil species should be interpreted as a gap in the section; also other explanations are worth investigating.

It is important to note that our main goal is locating an isotope event/excursion called the Mid-Ludfordian Carbon Isotope Excursion (MLCIE), but without having the necessary corresponding isotope data. Still, we do have fossils telling us about biotic changes caused by the temporally close Lau oceanic episode and/or conodont 
bioevent (Jeppsson \& Aldridge 2000; Jeppsson et al. 2006) and by other environmental phenomena, usually all closely tied with each other.

The Ohesaare core was our first object of interest when starting a carbon isotope project. The first results (Kaljo et al. 1994) on isotope markers were reported at the Erlangen meeting of the IGCP Project 293. The data showed nice excursions in the Wenlock, but nothing in the Ludlow. However, our team's full report (Kaljo et al. 1997), containing also data from the Priekule core (Latvia, location in Fig. 1), suggested that a significant gap existed in the upper Ludlow of the Ohesaare core (as had previously been shown biostratigraphically by Märss 1992). However, the exact age of the strata/gaps had remained somewhat vague. Still, data from Ventspils (fossil occurrences reported by Gailite et al. 1987; isotopes by Kaljo et al. 1998), Viduklè (Lithuania; Martma et al. 2005) and those from Poland, Bohemia and Gotland (summarized by Kaljo \& Martma 2006) allowed a more precise dating of the excursion. It was determined that the MLCIE belonged to the Mid-Ludfordian with its peak in an interzone just above the last appearance datum (LAD) of Neocucullograptus kozlowskii (details in Kozłowski \& Sobień 2012; Frýda \& Manda 2013; Kaljo et al. 2015).

On the basis of the MLCIE curve at Vidukle and the thickness data of strata, Martma et al. (2005) speculated that the whole excursion (total shift of 9.7\%o) corresponded to around $1.4 \mathrm{myr}$ (the steep peak or the final $4 \%$ rise took about $550 \mathrm{kyr}$ ). These numbers differ slightly from the analogous data of Cramer et al. (2015), based on $\mathrm{U}-\mathrm{Pb}$ zircon age determinations made from the Ludlow bentonites of Ukraine. But most importantly, both groups agreed that the environment, as reflected by the $\delta^{13} \mathrm{C}_{\text {carb }}$ excursion (all analyses quoted through the paper are $\mathrm{C}_{\text {carb }}$ ), had been changing rather rapidly (positive change in Ukraine $+2 \%$ per $125 \mathrm{kyr}$, in Vidukle per 137 kyr) throughout the middle Ludfordian ( $c a 1$ myr). Bearing in mind that some basic data for the Vidukle calculations have changed, here we prefer to use the modern results of Cramer et al. (2015) to convey an idea about the duration of the gap under study.

After analysing a remarkable amount of biostratigraphical data on the missing MLCIE, it seems reasonable to comment on a few current issues in regional stratigraphy concerning the Ludlow strata. This seems necessary, because the interval raises several new questions both in the latest 'semi-official' Silurian stratigraphic scheme/chart published by Männik (2014) and in Kiipli et al. (2011) who, using bentonite correlation, suggested to lower considerably the Wenlock-Ludlow boundary in the East Baltic. The suggestion seems especially intriguing because it concerns the Rootsiküla Formation containing, in some parts, a very poor or specific (hypersaline) fossil biota (Jarochowska et al.
2017). Today, we only accept that part of this formation is of Ludlow age (Viira \& Einasto 2003), but we wish to scale up the boundary problem to encourage further research in this direction.

Recently our earth science community celebrated the 200th anniversary of geological education in Estonia. Therefore, the authors would like to highlight several small but significant pieces of the history of study of the Ohesaare core and MLCIE that might serve as a source for new ideas also in the pages of this journal.

\section{GEOLOGICAL SETTING, MATERIAL AND METHODS}

General ideas about the Baltic Silurian epicontinental basin, with the main accent on its eastern part, have been published repeatedly (e.g. Bassett et al. 1989; Kaljo \& Nestor 1990; Nestor \& Einasto 1997; Baarli et al. 2003), showing that the sea formed, for the most part, a simple basin with regular depth-controlled sedimentary facies belts. Depending on the local tectonic structure, the shoreline configuration and facies zonation have changed from an open bay to a more gulf-like sea. Still, we think that Fig. 1 presents a sufficient overview of a probable environmental situation in the area slightly before the occurrence of our sought-after MLCIE.

In the history of the Estonian part of the Baltic Gulf (as termed by S. Laufeld at Gotland Ecostratigraphy Meeting 1981), a maximum sea level low stand occurred in the late Homerian (at the top of the Vesiku Beds $\left(\mathrm{K}_{1} \mathrm{Vs}\right)$ according to Nestor \& Einasto 1997, but Kiipli et al. 2011 place it in the early Ludlow). The latest Wenlock and early Gorstian were slowly transgressive (with some stratigraphical gaps locally), but the Ludfordian began with a new sea level lowering that resulted in a series of different gaps in the Ohesaare core (and elsewhere in the shallow-shelf area), including a significant one embracing the MLCIE. In the late Ludfordian, the normal shallow sea was once again widely restored (Kuressaare and Ventspils formations of Estonia and Latvia, respectively). Such a general history seems correct, however, details about the exact age and causes of the gaps need further discussion.

Figure 1 also shows the main locations of data discussed in the paper. Beside the Ohesaare core (closest to the shoreline), those in Latvia (Ventspils, Pavilosta and Priekule; Gailite et al. 1987; Kaljo et al. 2015) and Lithuania (Vidukle - Martma et al. 2005; Milaičiai-103 Paškevičius et al. 2012 and Spiridonov et al. 2017) represent deeper and more open sea facies (partly graptolite-bearing). The graptolite occurrences help to tie the Ohesaare core and the classical outcrops on Gotland, Sweden, all rich in shelly fossils, with the graptolite 


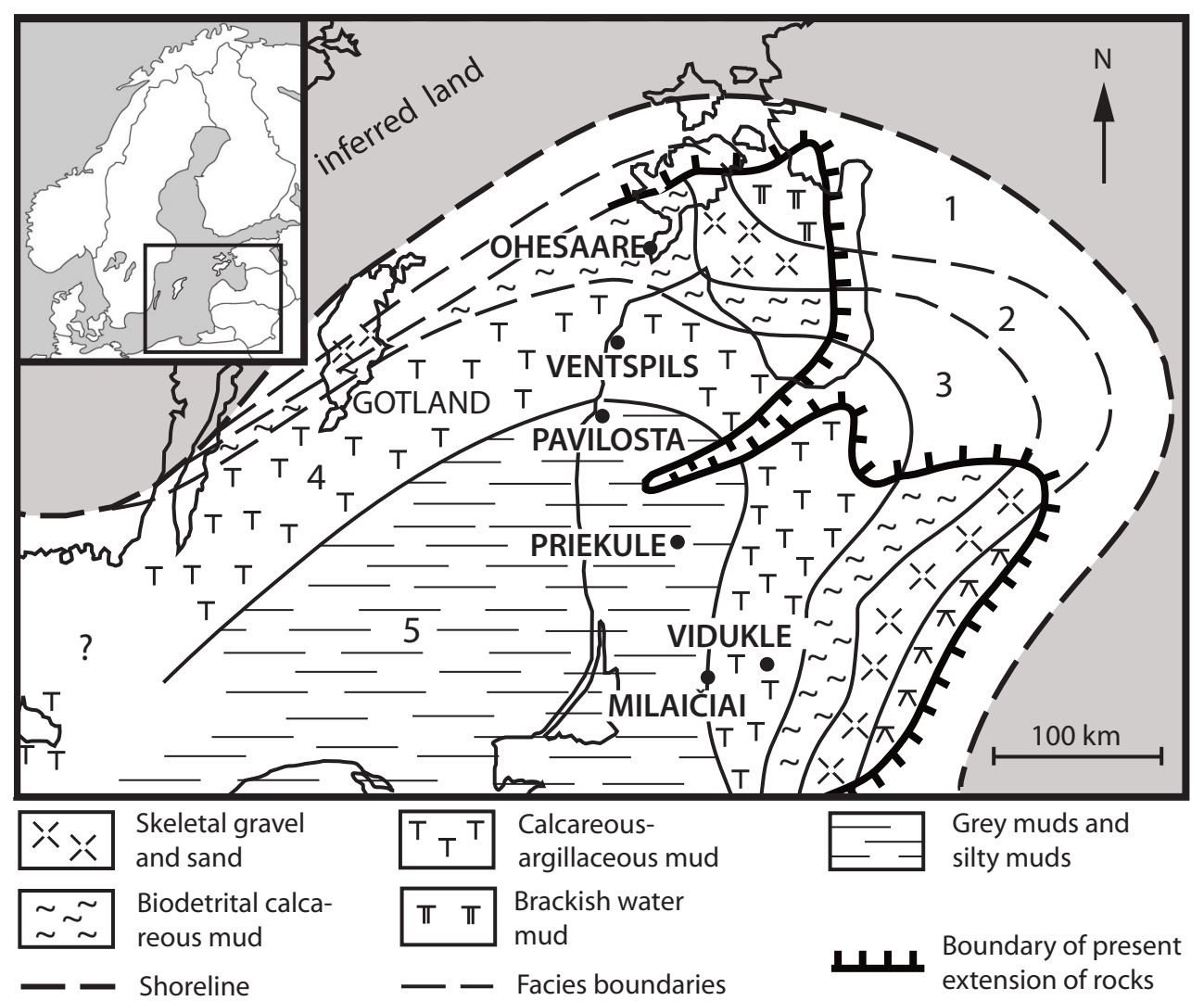

Fig. 1. Location of the discussed core sections on the background of the general facies zonation of the Baltic Gulf in the early middle Ludlow Epoch, modified from Bassett et al. (1989). Facies belts (the legend shows the presence of sediments, the white area postsedimentary erosion or no data): 1, inshore lagoonal/tidal flat; 2, high-energy shoal-bar; 3, open shelf, mid-ramp; 4, offshore shelf, outer ramp; 5, ramp/shelf depression.

biozonation of Poland, securing the exact stratigraphic dating of the event. All except Ohesaare also show a biostratigraphically identified interval with the MLCIE. In order to preserve the original stratigraphic datings of fossil occurrences, we mainly use local (regional) terminology of different units, listed in a stratigraphic correlation chart (Fig. 2) for easier reading of the text. The column of Polish graptolite biozones serves here as a firm framework of the Baltic and global biostratigraphic correlations. The original schema by Urbanek \& Teller (1997) has been modified according to Loydell (2012). The biozones in Ohesaare, with slight modifications, are mainly based on papers by Nestor (2012), Viira (1999), Männik (2014) and Märss \& Männik (2013). The Gotland column, in its upper part, presents a set of historical Hede's units used by Martinsson (1962) and Laufeld (1974) and, within the Hemse Group, also subunits (a-e) together with several new units introduced by Jeppsson (2005) and Jeppsson et al. $(2005,2006)$ summarizing the most recent innovations in Gotland stratigraphy (cf. Bremer \& Blom 2015). Still, some of them need further discussion (see Bremer et al. 2020; Jarochowska et al. 2021 and below).

When planning our 'search' in the Ohesaare core, we wanted to perform a detailed biodiversity analysis in order to get more data for discussion of possible changes in diversity patterns. Such an analysis needs a more detailed subdivision than shown in Fig. 2. Therefore, in Fig. 3 we subdivided the Torgu Formation into five nearly equally thick working units mostly with boundaries marked by discontinuity surfaces, thus allowing exact identification of the limits. At the bottom of the Ludlow Series, or in local terms of the Paadla Regional Stage $\left(\mathrm{K}_{2}\right)$, following the suggestion by Viira \& Einasto (2003), we accepted in the very bottom one more unit - the Soeginina Beds comprised with shallow shelf rocks of the diachronous Rootsiküla Formation. The overlying Torgu Formation consists of the most offsea rocks of the Paadla Regional Stage. Such a schema needs proving, but here we use it as the lowest unit of $\mathrm{K}_{2}$, in the same role as the introduced units $\mathrm{K}_{2} \mathrm{~T}_{1}-\mathrm{K}_{2} \mathrm{~T}_{5}$ (Fig. 3) that are meant only for the current analysis of biostratigraphical data. Boundary 
D. Kaljo et al.: A search for the MLCIE interval in Ohesaare

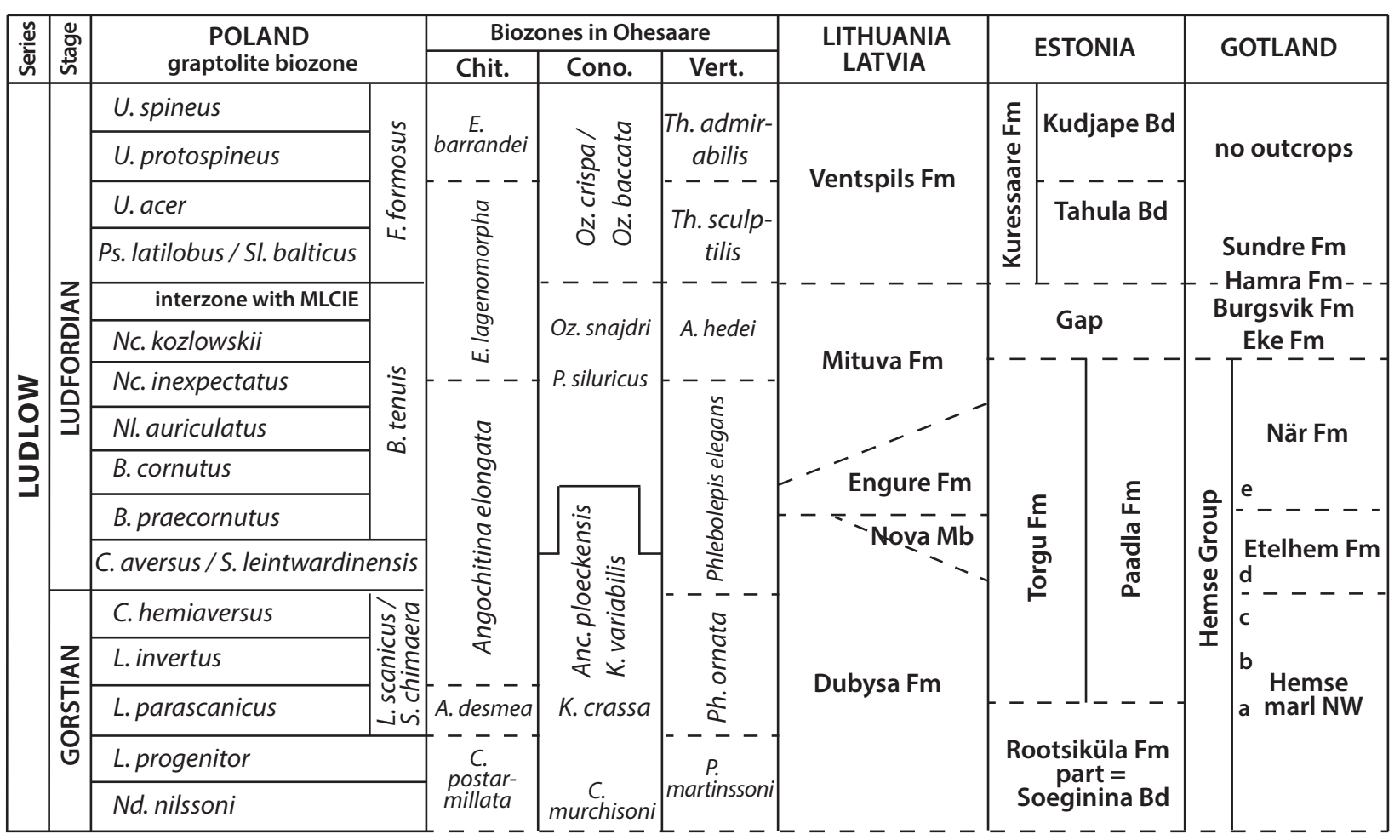

Fig. 2. The Baltic Ludlow stratigraphical terminology as used in the paper, presented in the manner of a usual correlation chart, but boundaries (dashed lines) are approximate, by columns in particular. See text for sources and explanations. Generic names in biozones are abbreviated as follows: graptolites - B., Bohemograptus; C., Cucullograptus; F., Formosograptus; L., Lobograptus; Nc., Neocucullograptus; Nd., Neodiversograptus; Nl., Neolobograptus; Ps., Pseudomonoclimacis; S., Saetograptus; Sl., Slovinograptus; U., Uncinatograptus; chitinozoans (Chit.) - A., Ancyrochitina; C., Conochitina; E., Eisenackitina; conodonts (Cono.) - Anc., Ancoradella; C., Ctenognathodus; K., Kockelella; Oz., Ozarkodina; P., Polygnathoides; vertebrates (Vert.) - A., Andreolepis; P., Paralogania; Ph., Phlebolepis; Th., Thelodus. Lithostratigraphic terms: Fm, Formation; Mb, Member; Bd, Beds.

discontinuity surfaces are surely of different significance. In Fig. 3, we have marked eight such discontinuities, two of which are the physically most striking (multiple): a four-fold series in the middle of the Torgu Formation, at a level correlated by Einasto (in Märss 1986, p. 84) with the bottom of the Himmiste Beds in the mid-Saaremaa area, and a two-fold one at the top of the Tahula Beds (top of $\mathrm{K}_{3} \mathrm{aT}$ ). Those could highlight some environmental episodes of the basin history against the background of regression that was the dominant trend throughout the Baltic Ludlow. Still, some discontinuities might only be local and mark a brief event, i.e. not affecting the wider common order of biozones or, more generally speaking, the normal pattern of biodiversity. Using these units, we analysed biodiversity changes within four fossil groups reported from the section, for comparing the local biodiversity pattern with neighbouring ones and on a wider scale, in order to find which of the discontinuities might mark the missing MLCIE. Bearing in mind that it had been the most striking isotopic event in the Phanerozoic, accompanied by various other processes, it should have left some visible impact traces also in sections without any known corresponding carbon isotope excursion.

To achieve the main goal of the study, we will first analyse the species composition of fossil assemblages by working units, and changes in biodiversity patterns at certain levels in the Ohesaare section, and second, we will compare them with those from neighbouring sections, in order to understand the differences. The sections are, first and foremost, the Ludlow outcrops and a few cored sections on Gotland, but also the cored rocks of Ventspils, Pavilosta and other drillings in the northern part of Kurzeme, Latvia (Fig. 1). These are also mostly shallow shelf environments, perhaps in some parts slightly deeperlying than the corresponding ones in Ohesaare, but most importantly, these rocks, like those of the Eke and Burgsvik formations (Calner et al. 2004, 2005), have survived in the highly dynamic Silurian environment. The palaeontological data set compiled for the study is rather rich and diverse (close to 150 species from four Ludlow fossil groups and several graptolites for support). Keeping a focus on our main goal that needed specific data for clear 
answers, we only used a part of all known species for detailed discussions below (Fig. 3). Most of these species are short-ranging, but there are also a few with a longer range that carry an important message. The result of such an analysis is rather like a usual biostratigraphical correlation with its typical uncertainties and problems due to facies differences. To overcome some dating obstacles, we used the Ventspils core data as a kind of model for the MLCIE interval within the Ludfordian in the mid-Baltic area. The Lithuanian cores Vidukle (Martma et al. 2005) and Milaičiai-103 (Paškevičius et al. 2012; Spiridonov et al. 2017) also contributed some data for correlation with the graptolite-dominated realm in Poland.

\section{DIVERSITY AND DISTRIBUTION OF SELECTED FOSSIL GROUPS IN THE OHESAARE CORE}

\section{General diversity patterns}

For biodiversity analysis of the Ohesaare core, we have at our disposal data on 115 fossil species from four biostratigraphically significant groups. Although some of the data have been published years ago, their value is still high. The most diverse group is ostracodes listed from the Ludlow rocks by Sarv (1968, 1971, 1977), within the limits accepted nowadays (Fig. 3), altogether 52 species, 21 of which occur in the Paadla Regional Stage $\left(\mathrm{K}_{2}\right)$ and 39 in the Kuressaare Regional Stage $\left(\mathrm{K}_{3} \mathrm{a}\right)$. The rapid increase in ostracode diversity during the Ludlow in Ohesaare seems a real burst in spite of, or even stressed by, some unfavourable environmental episodes marked at the very beginning of the Ludlow and later throughout the Paadla age. The biostratigraphical usefulness of ostracodes is supported by data from Gotland published in the pioneering papers of Martinsson $(1962,1967)$ and those from Latvia (Gailite 1967; Gailite et al. 1987). From the same beds, Nestor $(2007,2009,2012)$ reported 25 chitinozoan species (18 occur in $\mathrm{K}_{2}$ and 15 in $\mathrm{K}_{3} \mathrm{a}$ ) and compared their ranges with those of Gotland (Laufeld 1974; Nestor 1982) and against a global biozonal scheme (Verniers et al. 1995). The diversity numbers show a rather quick restoration after a deep low point in the topmost Homerian as well as in the late Ludfordian. Conodonts in the Ludlow interval of the core are much less diverse Viira $(1982,1999)$ and Viira \& Aldridge (1998) recorded only 13 species; Märss \& Männik (2013) added a couple of long-ranging Panderodus species. Half of them represent a very stable association of long-ranging species occurring nearly throughout the Paadla Regional Stage. The other half continue much higher and show a rather rapid innovation of the association - three first appearance datums (FADs) in both $\mathrm{K}_{2}$ and $\mathrm{K}_{3}$ a. That made the biostratigraphical renown of conodont species high and supported detailed correlations between Gotland (Jeppsson et al. 1994, 2006) and the East Baltic. During the early Silurian, vertebrates (agnathans and fishes) show a slow diversity increase followed by a 'boom' in the Ludlow. This pattern is visible also in the Ohesaare section where Märss (1986, 2001, 2006, 2019) and Blom et al. (2002) have recorded nine species in the Wenlock, but more than twice in the Ludlow - 25 (nine FADs in $\mathrm{K}_{2}$ and 13 in $\mathrm{K}_{3} \mathrm{a}$ ). However, it should be remembered that all these diversity numbers reflect the situation in one section; some other localities of the same formation or stage might add several other occurrences (cf. Märss 1986; Märss \& Männik 2013; Märss et al. 2014), or vice versa, but the general diversity pattern through time seems consistent. Data on the Ludlow vertebrates from Gotland (e.g. Fredholm 1988, 1989; Blom et al. 2002; Bremer et al. 2020; Jarochowska et al. 2021), as well as those by Karatajūtè-Talimaa \& Brazauskas (1994) from Lithuania, are in this sense extremely valuable in helping to formulate a fuller understanding of wider biodiversity patterns and dynamics.

Figure 3 visualizes the ranges of only 44 out of the 115 known species, mostly those familiar also from the closest neighbouring sections on Gotland (Sweden) and in Kurzeme (Latvia). Not shown in the figure are mainly long-ranging species and several rare findings mostly reported from only one locality that give scanty information in terms of our goal; however, several of them are still mentioned in the text for the sake of passing on their message.

\section{Diversity trends in time and an interim summary}

The fossil list of the Soeginina Beds $\left(\mathrm{K}_{2} \mathrm{Sn}\right.$ in Fig. 3$)$ in Ohesaare is rather poor with a shallow-shelf conodont Ctenognathodus murchisoni (Pander), earlier known as a guide fossil for the Rootsiküla Regional Stage of the Wenlock (Viira 1982), but recently recorded by Bremer et al. (2020) also from the Ludfordian Hamra and Sundre formations on Gotland. It is accompanied by three longranging species (all have FADs in the Wenlock, but LADs as noted here, in brackets): Ozarkodina confluens (Branson \& Mehl) (top of the Silurian), Oz. excavata (Branson \& Mehl) $\left(\mathrm{K}_{3} \mathrm{a}\right)$ and Oulodus siluricus (Branson \& Mehl) $\left(\mathrm{K}_{2} \mathrm{~T}_{5}\right)$. Some chitinozoans recorded in $\mathrm{K}_{2} \mathrm{~T}_{1}$ (e.g. Ancyrochitina sp., Conochitina rudda Sutherland), which have their FADs deeper in the section and may have some potential to be found in $\mathrm{K}_{2} \mathrm{Sn}$, are not shown in Fig. 3. Environmental conditions of the area were still similarly specific, even if somewhat normalized compared to the extreme ones in the late Homerian of Estonia, but giving an opposite diversity result to that as shown by Jarochowska et al. (2017). 


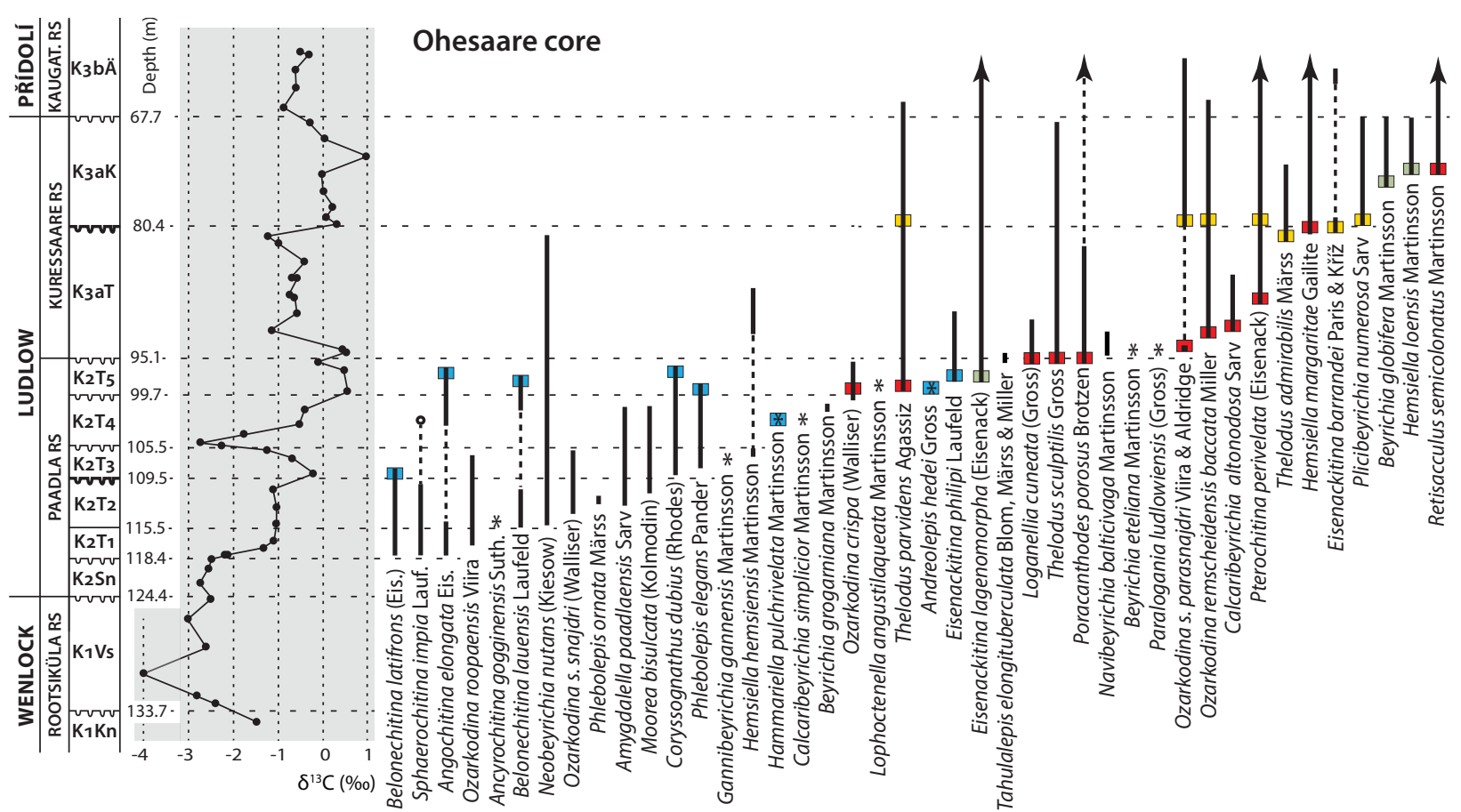

discontinuity
surface Fossil records: | continued; * single; i gap in records; $\bullet$ cf. $\quad$ In Ventspils: $\square$ just below; $\square$ transit; $\square$ just above; $\square$ high above

Fig. 3. Ranges of the most significant fossil species of chitinozoans, conodonts, microvertebrates and ostracodes through the Ludlow section of the Ohesaare core. Besides international series terms there are shown regional stages (RS), under- and overlying ones in part. The third column shows stratigraphical indices of official parts of the regional stage, and in part of the Torgu Formation, the working units $\left(T_{1}-T_{5}\right)$ introduced for this study. The Soeginina Beds as a part of the diachronous rock unit belongs to the Paadla Regional Stage. For comparison with the distribution of certain species in the Ventspils section, see coloured marks according to the legend and text. See text for data sources and other explanations.

A slow diversification of the fossil assemblage begins at the bottom of the Torgu Formation (unit $\mathrm{T}_{1}$ ), where four species appear, among them Belonechitina latifrons, Sphaerochitina impia and Angochitina elongata. The last one is an index species of the eponymous biozone (Nestor 2007), but all are also known from the Klinteberg Formation (Homerian) of Gotland (Laufeld 1974). Slightly higher in the section, Oz. roopaensis follows. Looking only at the occurrences in Ohesaare, the innovation rate seems high but the real number of FADs is only one, and nearly all species contributing to the innovation documented in $T_{1}$ show that it is in fact a continuation of an earlier process partly matching a local gap. Still, in the next unit $\left(\mathrm{T}_{2}\right)$, the process accelerated, producing 12 FADs including Belonechitina lauensis, Oz. s. snajdri, the short-ranging Phlebolepis ornata, a new Procephalaspis sp., a rather rare Ancyrochitina gogginensis and a group of eight ostracode species. Half of them are long-ranging: Neobeyrichia nutans (noted in Fig. 3), Amygdalella subclusa Martinsson, Cytherellina magna (Neckaja) and Orcofabella obscura Sarv (all have
LADs in $\mathrm{K}_{3} \mathrm{~b}$ ). Others, like Amygdalella paadlaensis, Clavofabella contracta Sarv and Moorea bisulcata (Kolmodin), occur in the main part of the Torgu Formation below $\mathrm{T}_{5}$. In the middle of the Torgu Formation (unit $\mathrm{T}_{3}$ ), three 'normally ranged' species are added to the list: Coryssognathus dubius, Phlebolepis elegans and Hemsiella hemsiensis (the last one is recorded at the top of the unit but missing in $\mathrm{K}_{2} \mathrm{~T}_{4-5}$ before reappearing in $\mathrm{K}_{3} \mathrm{aT}$ ) and the relatively rare Gannibeyrichia gannensis. The same pattern can also be noted about five new ostracode species partly listed in Fig. 3: Hammariella pulchrivelata, Calcaribeyrichia simplicior, Beyrichia grogarniana and also Cavellina primaria Sarv and 'Octonaria' perplexa Kummerow appear in $\mathrm{T}_{4}$, but do not continue further, except for the last species that has been recorded from the uppermost $\mathrm{K}_{3} \mathrm{aK}$. Most species in units $\mathrm{T}_{3}$ and $\mathrm{T}_{4}$ listed in Fig. 3, except for $O z$. crispa from the very top of $\mathrm{T}_{4}$ (see below), form the core of the characteristic Paadla fossil assemblage of the four groups discussed here. Strikingly, among the newcomers in $T_{3}$ and $T_{4}$, several are single occurrences or species with a very short range (e.g. 
Thelodus carinatus Märss) only in $\mathrm{T}_{4}$. This might be due to unsuitable environmental conditions at the end of the unit or because they are simply cut off by the gap we search for. Despite these signs, the assemblage in $T_{4}$ reaches a kind of acme of diversity (26 species, 12 of them long-ranging) and stability in composition (only five FADs). Most importantly, nearly all species reported from $\mathrm{T}_{2}-\mathrm{T}_{4}$ are also known from the Hemse Group of Gotland.

In $\mathrm{T}_{5}$, the picture gets more complicated, but the earlier trend of a high number of transitional species in the assemblage continues (18 from 29), regardless of the fact that none of the nine ostracode species recorded in $\mathrm{T}_{4}$ continues into $T_{5}$. Conodonts and vertebrates show a more stable association of long-ranging species, but a number of new species (11) appear in two events - at the bottom, which highlights the boundary between $\mathrm{T}_{4}$ and $\mathrm{T}_{5}$, and just below the top of $\mathrm{T}_{5}$. From the beginning of $\mathrm{T}_{5}$, Eisenackitina philipi, Eis. lagenomorpha, Thelodus parvidens and the first acanthodians in Ohesaare - the long-ranging Nostolepis striata Pander and Gomphonchus sandelensis (Pander) - appear. The latter two are clearly belated here compared to their much earlier (Gorstian) occurrences in Kolka and Ventspils (Märss 1986); their presence still signals that the sea became deeper. Coevally with the FAD of Andreolepis hedei (a biozonal index species) in the lower part of $\mathrm{T}_{5}$, yet another vertebrate biozone index species, Phlebolepis elegans (here as the LAD, see Fig. 3), and a new cyathaspidid, Archegonaspis sp., occur. The latter continues at the bottom of $\mathrm{K}_{3} \mathrm{aT}$, together with a group of four vertebrates: Thelodus sculptilis, Loganellia cuneata, Poracanthodes porosus and the anaspid Tahulalepis elongituberculata (Blom et al. 2002), all recorded from a sample (Märss 1986) just a few centimetres below the upper limit of $\mathrm{T}_{5}$ (at 95.15$95.17 \mathrm{~m}$ ). To get a full picture, let us add that $O z$. crispa occurring throughout $\mathrm{T}_{5}$ has its FAD less than $1 \mathrm{~m}$ below the bottom of $\mathrm{T}_{5}$ (Fig. 3). Ostracodes add two more names to the FAD list - long-ranging Kuresaaria circulata (Neckaja) and Lophoctenella angustilaqueata, described by Martinsson (1962) from the Hamra Formation at Hoburgen 1 on Gotland. The ranges documented above are highly harmonious in that the $\mathrm{T}_{5}$ assemblage links to those of $\mathrm{T}_{4}$ are rather weak; the last group of vertebrates, etc. are typical members of the Kuressaare and higher assemblages (including Hamra on Gotland).

Summarizing the above diversity and distribution data by groups of fossils, we can see several levels of intense innovation (marked by relatively numerous FADs) and some changes in diversity patterns, partly specific but partly also more or less common. Conodonts are scanty in number. Among them long-ranging species play a dominant role through the entire Torgu Formation and the most striking changes begin at the bottom of $\mathrm{K}_{3} \mathrm{aT}$. Still, in the Torgu Formation, the FADs/LADs of Oz. crispa $\left(\mathrm{T}_{4}\right.$ top- $\left.\mathrm{T}_{5}\right)$ and Coryssognathus dubius $\left(\mathrm{T}_{3}-\mathrm{T}_{5}\right)$ are significant. The range of the former has cast many doubts like 'it has appeared too early' or 'it is not a typical crispa'. Considering the detailed studies by Viira \& Aldridge (1998) and C. Corradini (oral statement in Tallinn, 2014), we discarded the latter doubt, and the former will be discussed in the final part of this paper.

Chitinozoans in Ohesaare take part in three important innovation events or episodes. The first one includes nine FADs in $\mathrm{T}_{1}$ and lower $\mathrm{T}_{2}$ that is dated as at the beginning of the Angochitina elongata Biozone in the middle Gorstian (Fig. 2; Verniers et al. 1995; Nestor 2012), the second brings five new chitinozoan species in $\mathrm{T}_{5}$ after a pause in the upper $T_{2}-T_{4}$ where no FADs were recorded. This 'pause' seems to have been an expression of a lowdiversity period of the wider Lau Event (Jeppsson et al. 2006). The beginning of the Tahula Beds also seems rather unfavourable for the group. During the third event, the late Ludfordian assemblage formed due to four new FADs documented in the upper part of $\mathrm{K}_{3} \mathrm{aT}$ (Pterochitina perivelata and Eisenackitina oviformis originate from the upper Hamra to lower Sundre formations of Gotland, Angochitina crassispina Eisenack was long-ranging and Ang. paucispinosa Miller et al. comes from the Ludfordian of UK). Higher in the formation $\left(\mathrm{K}_{3} \mathrm{aK}\right)$, three more FADs occur together with the Eisenackitina barrandei Biozone fauna.

Ostracodes quickly recovered from the unsuitable conditions in the early Gorstian. In $\mathrm{T}_{2}$, a group of eight new taxa appeared, half of them long-ranging and others (see above) occurring in the Torgu Formation below $T_{5}$. Through the mid- and upper units of the Torgu Formation, new ostracode appearances were regular but rather moderate (average three FADs per unit) until the next burst occurred (nine FADs) at the bottom of the Tahula Beds $\left(\mathrm{K}_{3} \mathrm{aT}\right)$. Still, there is an anomaly at the end of $\mathrm{T}_{4}$ when none of the five occurring ostracode species pass on to the next unit. Thus, the only ties the relatively scanty ostracode assemblage in $T_{5}$ has with those in the older parts of the Torgu Formation are the three long-ranging species that occurred in $\mathrm{T}_{2-3}$, which reappeared in $\mathrm{T}_{5}$ and continued into $\mathrm{K}_{3} \mathrm{a}$ and higher. Contrarily, two FADs in $\mathrm{T}_{5}$ emphasize the links with $\mathrm{K}_{3} \mathrm{a}$ and the Hamra Formation (see above). Innovations within the ostracode assemblage continued rather actively also in the latest Ludlow and higher in the Baltic (Fig. 3), but much less in Gotland outcrop sections and not touching problems of the Beyrichien-Kalk faunas from the Baltic Sea area (Martinsson 1967, 1977).

Vertebrates demonstrate a similar general pattern of diversity changes to that of ostracodes, despite a much smaller number of taxa having been recorded, especially in the lower Ludlow. Some details about the ranges of the first three biozones need further discussion, but here we 
would like to stress that significant diversification in the group begins within $\mathrm{T}_{5}$, highlighting the links of the latter with $\mathrm{K}_{3} \mathrm{a}$. The late Ludfordian assemblage is represented by e.g. Thelodus admirabilis, Trimerolepis tricava.

At the top of the Torgu Formation $\left(\mathrm{T}_{5}\right)$ and at the base of the Kuressaare Formation $\left(\mathrm{K}_{3} \mathrm{aT}\right)$, two discontinuity surfaces at the boundaries of $\mathrm{T}_{5}$ (Fig. 3) and the third in the middle of $\mathrm{T}_{5}$, at $97.4 \mathrm{~m}$, have been documented (Märss 1986, lithological description by E. Jürgenson and R. Einasto). These separate the FAD of Oz. crispa at the very end of $\mathrm{T}_{4}$ from the following three consecutive event levels (bottom and top of $\mathrm{T}_{5}$ and the lowermost Tahula Beds) with striking changes in fossil assemblages that yield important information (see Fig. 3) for correlation with the upper Ludlow section on Gotland (details in the next chapter).

These biodiversity changes and the ranges of certain significant taxa through the Ludlow in the Ohesaare core section directed us to an intermediate assertion that the discontinuity surfaces at 99.7 and $97.4 \mathrm{~m}$ might be good candidates for the MLCIE gap due to the strongest breaks in continuity of fossil assemblages through $\mathrm{T}_{5}$. The unit $\mathrm{T}_{5}$ is also a level where we can record the appearance of the first representatives of the Hamra Formation and/or higher assemblages of Gotland, but not those specific to the Eke and Burgsvik formations, except for a few transitional species.

\section{EVIDENCE DERIVED FROM COMPARISON WITH GOTLAND DATA}

\section{Discussion on biostratigraphy}

It seems to be a common understanding of all authors comparing the Ludlow sections on the Baltic islands of Saaremaa (Estonia) and Gotland (Sweden) that the Paadla Regional Stage and Hede's Hemse Group are, in general, well correlative regional strata. Diverging views (e.g. Jeppsson et al. 1994; Kaljo \& Martma 2006; Männik 2014; Bremer et al. 2020) usually refer to specific details of the correlation, and that is completely normal. In this chapter, we will try to find biostratigraphical links between neighbouring sections that might suggest a correlation between some stratigraphical levels in terms of the contemporary local nomenclature (Figs 2 and 3) which could help us to achieve our goal.

Several levels throughout the Torgu Formation with more first records of fossil species for the section were shown in the previous chapter. The interpretation of details of those records is highly significant for successful correlation. Among species known from different subdivisions of the Hemse Group of Gotland, there is a small fraction that have their FADs in the underlying Klinteberg
Formation or even deeper in the Wenlock. Five chitinozoan species (Fig. 3) with different ranges occur in the lower part of the Torgu Formation $\left(\mathrm{T}_{1}-\mathrm{T}_{2}\right)$, but their summary distribution pattern allows us to reach a credible dating. The explanation is that Belonechitina latifrons, Sphaerochitina impia and Angochitina elongata first appear in the upper Klinteberg Formation (Laufeld 1974), but the former two have their LADs in Hemse units $\mathrm{c}$ and $\mathrm{d}$, respectively, while the LAD of the last species is in the Eke Formation. It should be borne in mind that the Torgu units $T_{1}-T_{2}$ are preceded by the nearly barren Soeginina Beds and that there are some local gaps, which together correspond to the first two Ludlow chitinozoan biozones, not recorded in Ohesaare (Nestor 2007). Thus, it seems logical that, despite the links with Klinteberg, the bottom of the Torgu Formation (together with the beginning of the Ang. elongata Biozone in Ohesaare) is not located higher than unit c of the Hemse Group. Nestor (2012) correlated this level approximately with the middle to upper part of the Lobograptus scanicus graptolite Biozone (Fig. 2), but it may last up to the lower part of the Saetograptus leintwardinensis graptolite Biozone. This, together with the two mentioned chitinozoans (Laufeld 1974), is a rare direct dating, based on Saetograptus chimaera finds in Lilla Hallvard, Gotland (Jaeger 1981). In terms of correlation with the UK, it means that a level in the mid-Elton Formation, supported by a rare occurrence of Ancyrochitina gogginensis in $\mathrm{T}_{2}$ despite the much longer range of both biozonal indices and the last species Phlebolepis ornata, having in $\mathrm{T}_{2}$ a rather limited range, has in the lower part of the Hemse Marl and limestone a much wider distribution but all occurrences are within certain levels (units b and c).

The next two newcomers in $\mathrm{T}_{3}$ that also have a similar range in Ohesaare (LADs within $\mathrm{T}_{5}$, Fig. 3) are Coryssognathus dubius and Phlebolepis elegans, both simultaneously occurring also on Gotland. The former ranges mostly together with Polygnathoides siluricus, which is rare or missing both in Ohesaare and on Gotland. Jeppsson (2005, p. 278) has stressed that Cor. dubius is the 'most frequent ... sole indicator of the När Formation'. However, Corradini \& Serpagli (1999) list its occurrences also elsewhere from the middle to the top of the Ludlow (Oz. crispa Biozone). The latter co-occurrence is visible also in Ohesaare (Fig. 3 and discussion below). According to Fredholm (1988), Ph. elegans appears as low as in the Ancoradella ploeckensis Biozone at Linde 1, Rangsarve 1 and Medbys 1 on Gotland belonging to the middle part of the Hemse unit d, and in many outcrops its range continues up to the uppermost När Formation both with Pol. siluricus (in Millklint) and without it (e.g. Bomunds, Nyan 2). The ostracode data from $\mathrm{T}_{3}$ and $\mathrm{T}_{4}$, where all five short-ranging newcomers (Fig. 3) are known also from Gotland, recorded from different well-known outcrops 
(e.g. Amlings, Fakle, Hammarudden, Hulte, Gannes, Gogs 1, Grogarns, Sigvalde, Tänglings 3) of the Hemse Marl, Etelhem and När formations support this reasoning. The data referred to show that most of the listed units formalized in the limits of the lower Hemse Group (Fig. 2) can be correlated (perhaps not in full) with some part of the Ohesaare section. Thus, we think that the lack of Pol. siluricus (Jeppsson et al. 1994) in this section is partly overestimated; it should be interpreted as a normal När Formation scenario, where the index species is for some (perhaps environmental) reason locally missing (e.g. Fredholm (1988) used the terms 'with and without Pol. s.'). The reason for the gap needs further elaboration, but Fredholm (1988) seems to have taken a step in the right direction when discussing the differences in the appearance of the first acanthodians in Ventspils and the common FAD levels in Ohesaare (noted above) and Gotland outcrops. Another question is how to explain the existence and usage of the Pol. siluricus Biozone if the index species is missing in several localities. According to rules of biostratigraphy, the index species should occur in the eponymous biozone even if the upper boundary is defined by the beginning of the next Biozone. On the other hand, this does not mean that we see no gaps in Ohesaare, vice versa, there is at least one big gap in the right place for the MLCIE and maybe some more if they can be properly proved.

The most promising place to look for the stratigraphic gaps is in the working unit $\mathrm{T}_{5}$, and in particular the three discontinuities marking the two boundaries and the interruption in the middle. At the bottom of $\mathrm{T}_{5}$, Fig. 3 lists nine species occurring, among them nearly half FADs. Most essential seems the booming of microvertebrates, e.g. Thelodus parvidens, Andreolepis hedei, and from the category of FADs not shown - Archegonaspis sp., Nostolepis striata Pander and Gomphonchus sandelensis (Pander). The list shows a clear dominance of a preMLCIE assemblage. Most of the above species (except Lophoctenella angustilaqueata from the upper Hamra Formation) have their FADs in the När Formation on Gotland, where the $\delta^{13} \mathrm{C}$ values are not high. The long list of well-harmonizing occurrences seems to indicate that the disruption at $99.7 \mathrm{~m}$ was a short-lived one and of limited influence, but it clearly shows that the lower half of $\mathrm{T}_{5}$ has strong connections with the earlier fossil assemblages of the Paadla Regional Stage and the När Formation.

A step higher, in the upper half of the unit $T_{5}$, the innovation of vertebrates continues (Fig. 3) by the FADs of Tahulalepis elongituberculata, Th. sculptilis, Loganellia cuneata and Poracanthodes porosus. These occurrences are striking because these species appear just below and continue just above the overlying boundary discontinuity at $95.1 \mathrm{~m}$, stressing that this is not an important inter- ruption. On the other hand, three LADs, Ang. elongata, Cor. dubius and Oz. crispa, send a contradictory message from Gotland. The first two are typical biozonal species that range in the middle of the Hemse Group on Gotland, but the former reaches the MLCIE peak zone (Eke Formation) and the range of the latter usually (but not always) ends earlier in the När Formation (cf. Corradini \& Serpagli 1999; Bremer et al. 2020). Only Oz. crispa ranges much higher in the Hamra Formation, up to the upper Sundre Formation (cf. Bremer et al. 2020). Transitional species are mostly long-ranging (Eis. lagenomorpha, Th. parvidens) through the peak zone up to the upper Sundre Formation; only Eis. philipi remains within it (Burgsvik) and Neobeyrichia nutans occurs only in the När Formation, but much less frequently than in Ohesaare. The four FADs we saw in Ohesaare show the same trend on Gotland - one ( $\log$. cuneata) begins in the upper När Formation and three begin in the Burgsvik Formation, but all are also known from the Hamra Formation and two (Th. sculptilis, Log. cuneata) reach the top of the Sundre Formation. This assemblage (upper $\mathrm{T}_{5}$ ) does not send a straightforward message, but the occurrence of $\mathrm{Oz}$. crispa and several other conodonts (Fig. 3) suggests that the MLCIE gap embracing the Eke, Burgsvik and Lower Hamra formations is most likely located at a discontinuity (at $97.4 \mathrm{~m}$ ) in the middle of $\mathrm{T}_{5}$. A rich assemblage recorded at the bottom of the Tahula Beds (K3aT in Fig. 3, first $5 \mathrm{~m}$ ) and consisting of six FADs and singles (e.g. Oz. baccata, Oz. parasnajdri, Navibeyrichia balticivaga) and also Tahulaspis ordinata (not shown in Fig. 3) rather clearly supports that conclusion (Märss et al. 2014). The large number of FADs highlights the importance of the innovation process. When evaluating different occurrences, we should note the environment from a fossil originated, e.g. several fossils show FADs in Burgsvik with high $\mathrm{C}$ isotope values, but in Ohesaare ranging in Tahula and higher with low level values. It means that the late Ludfordian innovation began slightly earlier than previously thought and continued higher through the upper Tahula and Kudjape beds of the Kuressaare Regional Stage in Estonia, through the Ventspils Formation (see below) and analogous beds in the South Baltic area that are not represented on Gotland.

\section{The role of chemostratigraphy}

In order to make our discussion easier to understand, some introductory information should be given about the situation in the Ludlow of Gotland where the MLCIE embraces the Eke (rising limb of the curve and peak values), Burgsvik (specific plateau) and partly Hamra (falling limb of the curve) formations. According to previous publications, the $\delta^{13} \mathrm{C}$ excursion values differ slightly, but the most recent numbers recorded by Younes 
et al. (2017) are based mainly on well-dated samples from the Uddvide-1 core and from two somewhat less clearly dated outcrops (Husryggen 4 and Hoburgen cliff) on the Sudret Peninsula. All in all, a rather dense set of wholerock analyses covers nearly the entire MLCIE on Gotland. Through $10 \mathrm{~m}$ of the upper När Formation, up to sample $\mathrm{U} 19$ (at $48.23 \mathrm{~m}$ ), $\delta^{13} \mathrm{C}$ values vary close to $1-1.8 \%$, which seems appropriate for the starting point of the MLCIE rising limb of the curve at $c a 0.5 \mathrm{~m}$ below the bottom of the Eke Formation; $4.2 \mathrm{~m}$ higher, the $\delta^{13} \mathrm{C}$ value is already $6.3 \%$. The peak values $(8.03 \%$ and $7.73 \%$ ) of the excursion are recorded in the upper part of the Eke Formation. In the Burgsvik Formation, the curve of the $\delta^{13} \mathrm{C}$ values in sandstone has a bowl-like shape, with values at the centre being $2-3 \%$ lower than those at either end. The Oolite bed shows high values again (6-7\%) and in the lower part of the Hamra Formation, the values decrease gradually from $6.2 \%$ to $2.72 \%$. The values quoted here are taken from table 3 in Younes et al. (2017), but the datings of five samples under 'Sundre Formation' are corrected as they belong to the Hamra Formation, according to fig. 3 in the same Younes et al. paper and table 4 in Frýda et al. (2021). Only with great doubt can we accept the view of Bremer et al. (2020, p. 57) that the locality Rivviken 2 represents the lowermost Sundre Formation $\left(\delta^{13} \mathrm{C}\right.$ value $3.2 \%$ ), in the outcrop area of the Hamra Formation, as shown in fig. 1 (p. 53, op. cit.). Samtleben et al. (2000) list the same Rivviken 2 locality and value, but they date it to the HSB (=Hamra/Sundre Beds). For analyses, Samtleben et al. (2001) use brachiopod shells, which, as a rule, give slightly higher values, e.g. six $\delta^{13} \mathrm{C}$ values between $0.82 \%$ and $1.31 \%$, as reported from the Sundre Beds at Barshageudd 5. Despite the noted discrepancies, we think that, on Gotland, the MLCIE began half a metre below the Eke Formation and most probably ended higher in the Hamra Formation (conditionally at $30 \mathrm{~m}$ from the lower boundary; see fig. 3 in Younes et al. 2017). If that is true, then the thickness of the rocks accommodating the MLCIE must be $c a 78 \mathrm{~m}$, which is much more than typical for the central Baltic area (Latvia, Fig. 1), e.g. Ventspils $15 \mathrm{~m}$ (see below), Pavilosta $17 \mathrm{~m}$ (Kaljo et al. 2015), Priekule $28.3 \mathrm{~m}$ (Bowman et al. 2019). However, Viduklè in Lithuania with its parameters (thickness $53 \mathrm{~m}$, peak value $8.2 \%$, Martma et al. 2005) is more similar to the situation on Gotland (op. cit.). The thickness of rocks everywhere depends on local conditions and the Burgsvik Formation represents undoubtedly a specific, but not a very long event. Bearing in mind all the bio- and chemostratigraphic wealth of the Silurian on Gotland, it would be highly important for future studies to have an adequate description of the final part of the MLCIE (named LLCIE by Younes et al. 2017) in the Sudret sections.

\section{CHARACTERISTICS OF THE MLCIE INTERVAL IN THE CENTRAL EAST BALTIC AREA}

An interim summary of evidence for biodiversity trends based on the Ohesaare data seemed a reasonable way to solve our main problem, but we also need to see what the MLCIE interval in the central East Baltic area, within a more continuous section of deeper sea strata, looked like. To find a suitable data set, we decided to use various publications (see quotations in the text) about the Ludlow rocks, isotopes and corresponding fossils of the Ventspils D-3 drill core (Kurzeme, Latvia; location in Fig. 1). We chose that core because of its relative closeness to Ohesaare and a reasonable graptolite presence in its Gorstian Stage that would allow direct correlations of the core with Polish sections. This choice was supported by the fact that several members of our current research team have contributed to the bio- and chemostratigraphical studies of the core section (see the remark on p. 4 in Gailite et al. 1987, also papers by Märss 1986; Nestor 2007, 2009, 2011; Viira 1999). Gailite et al. (1987) provided the first official description of the Ventspils Formation in the stratotypic Ventspils D-3 core, determining its lower boundary at $453.0 \mathrm{~m}$ and the upper one at $428 \mathrm{~m}$. For some reason, in several papers the base is shown at a slightly different level, but from Märss \& Männik (2013) onwards, the levels are correct.

The MLCIE excursion was first identified in the Ventspils core by Kaljo et al. (1998) at the very top of the local Mituva Formation (Fig. 2), which is overlain by the Ventspils Formation, traditionally correlated with the Formosograptus formosus Biozone (details below and in Kaljo et al. 2015). The positive $\delta^{13} \mathrm{C}$ values begin with $+0.8 \%$ at $470.2 \mathrm{~m}$, followed by the rising limb of the curve, having three peaks at $465.4 \mathrm{~m}(+5.0 \%), 462.4 \mathrm{~m}$ $(+4.5 \%)$ and $458.7 \mathrm{~m}(+4.0 \%)$ forming the most elevated part of the excursion. The positive shift ends at $455.0 \mathrm{~m}$ $(+0.1 \%)$ with a rather clear turning point, since a clearly bigger value was determined in the next sample taken $1.4 \mathrm{~m}$ lower $(2.1 \%$ at $456.4 \mathrm{~m}$ ). Within that $15 \mathrm{~m}$ section (only $9 \mathrm{~m}$ if we just consider values above 3\%o) both the rising and falling limbs of the excursion curve are rather steep. These data indicate that the MLCIE in the Ventspils area was a short-lived but intense event. We note a quick rise to $5 \%$ within only $4.8 \mathrm{~m}$ of sedimentary rock thickness. After that the values remain mostly high for $c a 7 \mathrm{~m}$ and decrease from $4.0 \%$ to baseline values within just $3.7 \mathrm{~m}$ of sedimentary rock thickness. Comparing these parameters with those in Viduklè (Martma et al. 2005), we see great similarities in the peak part of the excursion, but clear differences in the basis. The basal parts of the excursion in Vidukle are much wider (slower rising/ falling), similarly to those on Gotland, which indicate some local geological phenomenon causing faster sedi- 
mentation in the area or some other limiting factors north of Kurzeme, e.g. gaps.

The above-described $\mathrm{C}$ isotope event levels of the MLCIE in Ventspils serve well as chemostratigraphical markers, especially when accompanied by biostratigraphical criteria. In order to expand upon the background to the MLCIE and increase its value in chronostratigraphy, we add below our data on the distribution of chitinozoans, conodonts, ostracodes and vertebrates defining the boundaries of the strata hosting the MLCIE with the closely under- and overlying sedimentary rocks. The beginning of the Ludlow Series in the core section can be clearly dated by graptolite occurrences from lower in the core by the LAD of Neodiversograptus nilssoni (Lapworth) at $659.6 \mathrm{~m}$, but lithologically is transitional at $662.0 \mathrm{~m}$ (Gailite et al. 1987). The Gorstian part of the section comprises most of those graptolite index species up to the LADs of Pristiograptus tumescens minor (Wood) at $574.3 \mathrm{~m}$ and Bohemograptus bohemicus (Barrande) at $573.9 \mathrm{~m}$ needed to determine the Ludlow Series. The Ludfordian part has no such classical markers, but the MLCIE, together with the distribution pattern of microfossils discussed here, allows us to reconstruct a plausible biostratigraphy. Keeping our goal in mind, we focus only on fossil species noted also in the Ohesaare and/or Gotland sections. For this, it is very important to fix FADs or LADs precisely, not just their approximate ranges.

In order to make the text easier to follow, we have summarized the Ventspils core fossil data into three distribution groups: (1) A species group 'just below' comprises fossils that occur in the lower-middle Ludlow, including the Mituva Formation below the MLCIE peak zone (depth 470-455 m) or have their LADs in the peak zone. These species help to date the bottom of the peak zone. (2) Transitional species, including those that occur below and above the peak zone, but may be missing in the peak zone itself. (3) The species 'just above' first appear within the peak zone or slightly higher, in the Ventspils Formation. These three groups are also shown in Fig. 3 by coloured marks that vividly highlight the similarity of fossil distributions in the Ohesaare and Ventspils sections. Transferring this classification, based on chemostratigraphy, to the Gotland section, 'just below' = the upper Hemse/När Formation; peak zone = the Eke, Burgsvik and lower(?) Hamra formations; 'just above' = the upper Hamra and Sundre formations plus a gap/not represented. Now let us test the pattern with a biostratigraphical comparison. When commenting on the distribution of several characteristic fossils in the Ventspils core, depths of their LADs or FADs (in the case of the 'just above' species) are given in brackets.

According to Nestor (2009), several chitinozoans widely known from different parts of the Hemse Group
(Laufeld 1974) belong to the 'just below' group. Among them, Belonechitina latifrons (at $490 \mathrm{~m}$ ) is limited to lower levels below the När Formation on Gotland, but others, like Belonechitina lauensis (at $472 \mathrm{~m}$ ) and Angochitina elongata (at $476.7 \mathrm{~m}$ ), reach the Eke Formation and Ancyrochitina diabolus (at $480 \mathrm{~m}$ ) ranges even higher, the Sundre Formation. The occurrences in the Ventspils section are in good harmony with their corresponding ranges on Gotland and in Ohesaare, but the LADs clearly fall into an earlier period than expected (before the MLCIE, correlative to the Eke Formation or higher). The range of Eisenackitina philipi (cf. at $527.8 \mathrm{~m}$; $512-468 \mathrm{~m}$ ) begins slightly earlier but reaches the peak zone $\left(\delta^{13} \mathrm{C}\right.$ value at $468.7 \mathrm{~m}$ is $\left.+2.5 \%\right)$ at the level that can be correlated with the lower part of the Eke Formation. In Ohesaare and on Gotland, Eis. philipi occurs together with early representatives of a transitional species, Eis. lagenomorpha (at 516-274 m), and this is so also in Ventspils where the latter species continues ranging higher, through the MLCIE and the Lau Event, which is its common interval in the Baltic and elsewhere. Cingulochitina hedei was recorded in a completely 'wrong' place in Ventspils (at 485.1-476.7 m). However, two more specimens have been found much higher as well, at 412-404 m, which is the 'right' place); the species also occurs on Gotland in the Hamra and Sundre formations (Laufeld 1974) and in the Pavilosta core at the bottom of the Minija Formation (Nestor 2011).

When generalizing the chitinozoan data, several species can be regarded as promising ties between the discussed sections, but some of them appear 'too early'. This makes us cautious, especially if it is evident (fig. 4 in Nestor 2009) that the extinctions evoked by the Lau Event as defined by Jeppsson (1990) and Jeppsson et al. (2006) clearly began before the MLCIE excursion even started. It seems plausible that the event had certain effect on the distribution of biota, chitinozoans in particular, but every case of a 'too early' appearance may certainly have its own individual reason, not necessarily being the result of a large-scale event.

Ostracodes are well represented in all of the discussed sections and can yield useful information for dating. Gailite et al. (1987) listed ca 30 species from the Mituva and Ventspils formations, two-thirds of which are also known from Ohesaare and only a quarter from Gotland, because analogous beds are partly missing there or a certain group has not been studied. In general, ostracodes in the lower Ludfordian of the Ventspils core are moderately diverse with some disappearances in the 'just below' and 'early peak' zones, but a new energetic innovation begins at the very bottom of the 'just above' zone and continues through several higher levels. The 'just below' group is rather limited, but ostracodes like 
Hammariella pulchrivelata and Neobeyrichia lauensis (both at $478.0 \mathrm{~m}$ ) show LADs in good harmony with their pattern elsewhere. Neobeyrichia ctenophora at $485.5 \mathrm{~m}$ is not equally harmonious - it should also occur higher like on Gotland (in transitional category). An important conodont, Coryssognathus dubius, ranges (according to Märss \& Männik 2013) from 573.0 to 470.4 m, together with the vertebrate zonal index species Phlebolepis elegans (at 552.5-474.8 m) and Andreolepis hedei (at 484.5-472.4 m). In the top part of their range, these are accompanied by Archegonaspis sp.; this is clearly a very similar distribution pattern to those in Ohesaare (upper Paadla/Torgu formations, see also Fig. 3) and on Gotland (the uppermost Hemse/När formations).

The transitional group includes mostly long-ranging species such as Amygdalella subclusa, Kuresaaria angulata, K. circulata, Nostolepis striata and Gomphonchus sandelensis that continue occurring in higher strata as well, in the upper Ludlow and Přídolí. Among them we also find Eisenackitina lagenomorpha, as mentioned above. A few transitional species such as Hemsiella loensis (at 485.5-450.4 m) and Scaldianella personata (at 478$450.4 \mathrm{~m}$ ) represent an assemblage that is known from the Eke and Hamra formations on Gotland and extends into the few bottom metres of the Ventspils Formation in Latvia. We accept their range through the MLCIE peak zone based on samples at 476 and $452 \mathrm{~m}$ despite a $20 \mathrm{~m}$ gap in ostracode samples between the noted ones. By definition, Beyrichia globifera is a transitional species (at $555-428.3 \mathrm{~m}$ ), but only three finds are known below $442.4 \mathrm{~m}$. The situation is the same in Ohesaare, where this species occurs only in $\mathrm{K}_{3} \mathrm{aK}$, but vice versa on Gotland where it is widely found in the lower part, in eight outcrops in the upper Hemse/När Formation, but higher in the Eke Formation only a LAD is recorded from Lau Bakar. The occurrence of Oz. s. snajdri (at 464.4-460.2 m) in the peak zone is also interesting, but to interpret its meaning, we need to return (see below) to the Oz. crispa problem in Ohesaare.

The category 'just above' is rather numerous, but the most intriguing records are the early FADs (at $456.0 \mathrm{~m}$ ) of the conodonts $\mathrm{Oz}$. baccata (LAD at $407.6 \mathrm{~m}$ ), Oulodus elegans (LAD at $267.0 \mathrm{~m}$ ) and a group of the typical lower Kuressaare/Ventspils microvertebrates (Thelodus parvidens, Th. sculptilis, Loganellia cuneata, Poracanthodes porosus). This observation seems important because it links the very end of the peak zone with certain biotic events with potential uses for correlation (details in Gotland biostratigraphy) of rocks below the bottom of the Ventspils Formation. All of the listed fossils are also reported from Ohesaare and Gotland, fixing rather clearly this early innovation level in all three localities (see coloured marks in Fig. 3). Ostracodes demonstrate a burst of innovation a few metres higher. At a depth of $452.0 \mathrm{~m}$, Gailite et al.
(1987) recorded FADs of nine species, seven of which are also known from Ohesaare, e.g. short-ranging Berolinella praevia Sarv is limited to $\mathrm{K}_{3} \mathrm{aT}$, but most of them (Limbinariella macroreticulata Sarv, Clavofabella nodosa Sarv) represent the assemblage of $\mathrm{K}_{3} \mathrm{aK}$. The only species known from Gotland, Retisacculus semicolonatus, occurs in the lower Hamra Formation and in Ventspils goes through to the Minija Formation. The next sample, at $450.4 \mathrm{~m}$, and the following ones taken at 1-2 m intervals up to the top of the Ventspils Formation, reveal a row of stepwise first appearances of ten new ostracode species as reported by Gailite et al. (1987). Among those, seven also occur in Ohesaare, mainly in $\mathrm{K}_{3} \mathrm{aK}$, but longranging Sleia equestris (transitional species on Gotland), Calcaribeyrichia altonodosa, Hemsiella margaritae (Fig. 3) and Leiocyamus limpidus (transitional species in Ohesaare) are also known from older beds. At about the same level, the problematic index conodont, Oz. crispa, appears (FAD at $446.3 \mathrm{~m}$, ranging, with only two small gaps, up to $407.6 \mathrm{~m}$ in the lower Minija Formation of the Př́idolí). This position seems to fit best for an index species of the uppermost Ludlow conodont Biozone, but the beginning of the biozone is still not clear enough.

When summarizing the Ventspils core data, we would like to stress a few most informative aspects for our goal. (1) Biostratigraphical signals of fossils belonging to the 'just below' category are generally in good harmony with those in other localities studied. The occurrences of Coryssognathus dubius, Phlebolepis elegans and Andreolepis hedei yield the most exact information, but the ostracodes Neobeyrichia lauensis and Hemsiella loensis mark the MLCIE bottom equally well. (2) Chitinozoans suffered most from the Lau Event, but in the 'just above' category, together with ostracodes and microvertebrates, they provided useful hints for our search. The occurrence of these species clearly supports (Fig. 3, coloured marks) our placing the MLCIE gap within $\mathrm{T}_{5}$ and, at the same time, leaving the LAD of $P h$. elegans below the gap. Placing the top of $\mathrm{T}_{5}$ above the peak zone depends substantially on isotope values, but at the same time a correlation based on the current level within the lower Hamra Formation highlights a valuable innovation event. (3) Biostratigraphically, the early FADs of $\mathrm{Oz}$. baccata together with several others (above) mark well the beginning of a post MLCIE time interval (details below) and the corresponding biodiversity pattern forms a needed timeframe for the upper Ludfordian in the shelly faunal area of the East Baltic.

\section{SUMMARY DISCUSSION}

The above presentation and interpretation of data concentrated on finding the most plausible level for the 
missing MLCIE in Ohesaare. Our 'search' began with biodiversity data from the Ohesaare core and resulted in a preliminary suggestion to place the MLCIE 'gap' at a discontinuity surface (depth $97.4 \mathrm{~m}$ ) in the middle of the working unit $\mathrm{T}_{5}$ towards the top of the Torgu Formation (Figs 2, 3). The local bio- and chemostratigraphical patterns were compared to analogous data sets from Gotland and Ventspils (see the corresponding chapters). In general, all three sets help to restore the original order of assemblages (Ph. elegans and others below the MLCIE and $O z$. crispa and others above it) and highlight dynamic innovation events after the low-diversity episode of the Lau Event. However, some aspects need further attention. The most important of these are linked to the distribution of $O z$. crispa in units $\mathrm{T}_{4-5}$. This conodont has been a biozonal index species for the uppermost biozone of the Ludlow ever since the early papers by Walliser (see history in Corradini 2009). Jeppsson et al. (2006) assumed the same position for the alternating (with and without) occurrences of species in the Hamra and Sundre formations of Gotland (cf. Bremer et al. 2020) regardless of the erosional upper boundary of the latter formation. Several missing fossils that appear higher in the Ventspils and Kuressaare formations (see above) indicate that the section in the Sudret area has suffered from erosional loss, but occurrences of $\mathrm{Oz}$. crispa in the Hamra-Sundre formations do not support this suggestion. Let us discuss briefly the situation.

The uppermost Ludlow and lower Přídolí sections are much richer in fossil finds in the East Baltic shelly facies area. Viira \& Aldridge (1998), Viira (1999) and Männik (2014) show that in some localities the Oz. crispa Biozone and $\mathrm{Oz}$. baccata/Oz. parasnajdri Biozone continue into the lower Přídolí (see also Kaljo et al. 2012). The corresponding ranges in the Ventspils core suggest that, locally, one or the other may prevail or appear somewhat earlier (e.g. Oz. baccata before Oz. crispa in Ventspils), but in general, Oz. crispa and Oz. baccata together compose a sort of united biozonal association. The first finds of $\mathrm{Oz}$. parasnajdri in Ohesaare were rare (FAD at $93.4 \mathrm{~m}$, the second only at $79.2 \mathrm{~m}$ at the bottom of the Kudjape Beds). The 'too early' occurrence of $O z$. crispa shows a similar pattern in $\mathrm{T}_{4-5}$ (see both above and Fig. 3 ). On the other hand, keeping in mind the low diversity conditions of the Lau Event and the environment where hiatuses (a series of discontinuities) in the area are rather common, such rare occurrences may happen for various reasons and, therefore, any conclusions drawn from these should be carefully considered. Although we were able to find a gap for the MLCIE, some earlier ones disturbing the diversity pattern are still awaiting proper study.

Placing the MLCIE peak zone in the Ohesaare core at the level of a discontinuity surface in the middle of unit
$\mathrm{T}_{5}$ means that the first rare specimens of Oz. crispa, together with those of Oz. snajdri s.l., may appear much deeper at any incidental level of the early MLCIE interval. Considering Polish graptolite and carbon isotope data (Urbanek 1997; Kozłowski \& Sobień 2012), Kaljo et al. (2015) argued that the MLCIE begins and ends within the Neocucullograptus kozlowskii Biozone, including the overlying interzone that is still located below the latest Ludfordian in the sense of Urbanek \& Teller (1997) and Cramer et al. (2011). In terms of Gotland, it means that the Eke, Burgsvik and Hamra (part, see above) formations with the increased $\delta^{13} \mathrm{C}$ values represent the midLudfordian. The rest of the overlying Hamra and Sundre formations contain $\mathrm{Oz}$. crispa, which means that older members of this association may occur in lower parts of the Kuressaare (including the upper $\mathrm{T}_{5}$ unit) and Ventspils formations, and as we know, both actually do contain $O z$. baccata and $\mathrm{Oz}$. crispa. On the other hand, according to Spiridonov et al. (2017), in the Milaičiai core (Lithuania, Fig. 1), the MLCIE peak zone (at 1232-1226 m) occurs 'just above' the $B$. bohemicus tenuis range (LAD at $1234 \mathrm{~m}$ ) and $c a 10 \mathrm{~m}$ below the FAD of Slovinograptus balticus (at $1218-1210 \mathrm{~m}$ ) in the lower part of the Mituva Formation. The latter fossil marks the lower boundary of the Formosograptus formosus Biozone. The Oz. baccataOz. crispa Biozone is noted much higher (at 1181-1170 m) in the Ventspils Formation, but there only $O z$. baccata was found, despite the late $O z$. crispa occurrences in the Ventspils core up to the bottom of the Prídolí (Viira 1999). The above demonstrates the well-known diachroneity issue with lithostratigraphical units such as the Baltic formations. Yet, since the range of Oz. crispa is rather long, its interpretation needs to be mindful. New approaches and study methods might give a better understanding of the whole data set. For example, the occurrences of $\mathrm{Oz}$. baccata 'just above' the MLCIE in Ventspils and the 'gap' in Ohesaare, together with evidence provided by certain chitinozoans, microvertebrates and ostracodes (see the corresponding chapters), give a good overview of ecostratigraphical differences, but provide no definite chronostratigraphical guide. Additional data from Spiridonov et al. (2017) about the situation in the Milaičiai core show clearly that the $O z$. baccata Biozone and the accompanying fossils, such as e.g. Eisenackitina barrandei, Thelodus admirabilis and Hemsiella margaritae, belong to the late Ludfordian assemblage. The explanation seems to lie in a short-duration transgression event and, in the case of $\mathrm{Oz}$. crispa in the Sudret outcrops, it might be an earlier not the latest morph. All those difficulties with formulating a logical procedure might refer to another gap that influenced the fossil distribution pattern. 


\section{CONCLUSIONS}

1. A detailed analysis of the dynamics of the taxonomic content of Ludlow chitinozoans, conodonts, ostracodes, microvertebrates and their distribution patterns in the Ohesaare core section allows us to successfully establish the position of the MLCIE (even without $\delta^{13} \mathrm{C}$ values) within a significant gap slightly below the top of the Torgu Formation.

2. In achieving such a positive result, comparison with biostratigraphical and chemostratigraphical data sets from the Ludlow of Gotland (Sweden) and the Ventspils core (Kurzeme, Latvia) played a key role. Aspects of ecostratigraphy and the impact on biota of the environmental processes resulting from the Lau Event cannot be ignored.

3. Several refinements in the Ludlow stratigraphy of Estonia based on discussions in this paper are to be expected.

Acknowledgements. We are grateful to D. K. Loydell and an anonymous reviewer for their constructive remarks and suggestions. The manuscript of this paper was compiled at the Department of Geology, Tallinn University of Technology, and using their facilities. Many thanks to G. Baranov for the help with computer graphics and to H. Pohl-Raidla for linguistic aid. The publication costs of this article were partially covered by the Estonian Academy of Sciences.

\section{REFERENCES}

Aaloe, A. \& Jürgenson, E. 1977. General rock types of the Baltic Silurian. In Facies and Fauna of the Baltic Silurian (Kaljo, D., ed.), pp. 14-44. Institute of Geology, Estonian Academy of Sciences, Tallinn [in Russian, with English summary].

Aaloe, A. O. \& Kaljo, D. L. 1962. A preliminary report on Silurian strata in Ohesaare boring. Eesti NSV TA Geoloogia Instituudi Uurimused, 10, 41-54 [in Russian, with English summary].

Baarli, B. G., Johnson, M. E. \& Antoshkina, A. I. 2003. Silurian stratigraphy and paleogeography of Baltica. In Silurian Lands and Seas: Paleogeography Outside of Laurentia (Landing, E. \& Johnson, M. E., eds), New York State Museum Bulletin, 493, 3-34.

Bassett, M. G., Kaljo, D. \& Teller, L. 1989. The Baltic region. In A Global Standard for the Silurian System (Holland, C. H. \& Bassett, M. G., eds), National Museum of Wales. Geological Series, 9, 158-170.

Blom, H., Märss, T. \& Miller, C. G. 2002. Silurian and earliest Devonian birkeniid anaspids from the Northern Hemisphere. Transactions of the Royal Society of Edinburg, Earth Sciences, 92, 263-323.

Bowman, C. N., Young, S. A., Kaljo, D., Eriksson, M. E., Them II, T. R., Hints, O., Martma, T. \& Owens, J. D. 2019. Linking the progressive expansion of reducing conditions to a stepwise mass extinction event in the late Silurian oceans. Geology, 47, 968-972.

Bremer, O. \& Blom, H. 2015. An updated stratigraphic and environmental framework for the distribution of Silurian vertebrates on Gotland. Estonian Journal of Earth Sciences, 64, 13-18.

Bremer, O., Jarochowska, E. \& Märss, T. 2020. Vertebrate remains and conodonts in the upper Silurian Hamra and Sundre formations of Gotland, Sweden. GFF, 142, 52-80.

Calner, M., Jeppsson, L. \& Munnecke, A. 2004. The Silurian of Gotland - Part I: Review of the stratigraphic framework, event stratigraphy, and stable carbon and oxygen isotope development. Erlanger geologische Abhandlungen, Sonderband, 5, 113-131.

Calner, M., Jeppsson, L. \& Eriksson, M. E. 2005. The Baltic basin and the Silurian strata of Gotland, Sweden. In The Dynamic Silurian Earth (Eriksson, M. E. \& Calner, M., eds), SGU Rapporter och meddelanden, 121, 6-13.

Corradini, C. 2009. Looking for a late Silurian Standard Conodont zonation: still a long way to go. Rendiconti della Societa Paleontologica Italiana, 3, 273-274.

Corradini, C. \& Serpagli, E. 1999. A Silurian conodont biozonation from the late Llandovery to end Pridoli in Sardinia (Italy). Bollettino della Societa Paleontologica Italiana, 37, 255-273.

Cramer, B. D., Brett, C. E., Melchin, M. J., Männik, P., Kleffner, M. A., McLaughlin, P. I., Loydell, D. K., Munnecke, A., Jeppsson, L., Corradini, C., Brunton, F. R. \& Saltzman, M. R. 2011. Revised correlation of Silurian Provincial Series of North America with global and regional chronostratigraphic units and $\delta^{13} \mathrm{C}_{\text {carb }}$ chemostratigraphy. Lethaia, 44, 185-202.

Cramer, B. D., Schmitz, M. D., Huff, W. D. \& Bergström, S. M. 2015. High-precision $\mathrm{U}-\mathrm{Pb}$ zircon age constraints on the duration of rapid biogeochemical events during the Ludlow Epoch (Silurian Period). Journal of the Geological Society, London, 172, 157-160.

Fredholm, D. 1988. Vertebrate biostratigraphy of the Ludlovian Hemse Beds of Gotland, Sweden. GFF, 110, 237-253.

Fredholm, D. 1989. Silurian vertebrates of Gotland, Sweden. Lund Publications in Geology, 76, 1-47.

Frýda, J. \& Manda, Š. 2013. A long-lasting steady period of isotopically heavy carbon in the late Silurian ocean: evolution of the $\delta^{13} \mathrm{C}$ record and its significance for an integrated $\delta^{13} \mathrm{C}$, graptolite and conodont stratigraphy. Bulletin of Geosciences, 88, 463-482.

Frýda, J., Lehnert, O., Joachimski, M. M., Männik, P., Kubajko, M., Mergl, M., Farkaš, J. \& Frýdová, B. 2021. The MidLudfordian (late Silurian) glaciation: A link with global changes in ocean chemistry and ecosystem overturns. EarthScience Reviews, 220, 103652.

Gailite, L. K. 1967. Glava 3. Opisanie ostrakod [Chapter 3. Description of ostracods]. In Stratigrafiya, fauna i usloviya obrazovaniya silurijskikh porod Srednej Pribaltiki [Stratigraphy, Fauna and Conditions of Formation of the Silurian Rocks of the Central Baltic] (Gailite, L. K., Rybnikova, M. V. \& Ulst, R. Zh.), pp. 89-168. Zinatne, Riga [in Russian]. 
Gailite, L. K., Ulst, R. Zh. \& Yakovleva, V. I. 1987. Stratotipicheskie i tipovye razrezy silura Latvii [Silurian Stratotypes and Key Sections of Latvia]. Zinatne, Riga, 184 pp. [in Russian].

Jaeger, H. 1981. Comments on the graptolite chronology of Gotland. In Proceedings of Project Ecostratigraphy Plenary Meeting, Gotland, 1981 (Laufeld, S., ed.), Sveriges geologiska undersökning. Rapporter och Meddelanden, 25, 12.

Jarochowska, E., Viira, V., Einasto, R., Nawrot, R., Bremer, O., Männik, P. \& Munnecke, A. 2017. Conodonts in Silurian hypersaline environments. Specialized and unexpectedly diverse. Geology, 45, 3-6.

Jarochowska, E., Bremer, O., Yiu, A., Märss, T., Blom, H., Mörs, T. \& Vajda, V. 2021. Revision of thelodonts, acanthodians, conodonts, and the depositional environments in the Burgen outlier (Ludlow, Silurian) of Gotland, Sweden. $G F F, \mathbf{1 4 3}, 168-189$.

Jeppsson, L.1990. An oceanic model for lithological and faunal changes tested on the Silurian record. Journal of the Geological Society, London, 147, 663-674.

Jeppsson, L. 2005. Conodont-based revisions of the Late Ludfordian on Gotland, Sweden. GFF, 127, 273-282.

Jeppsson, L. \& Aldridge, R. J. 2000. Ludlow (Late Silurian) oceanic episodes and events. Journal of the Geological Society, London, 157, 1137-1148.

Jeppsson, L., Viira, V. \& Männik, P. 1994. Silurian conodontbased correlations between Gotland (Sweden) and Saaremaa (Estonia). Geological Magazine, 131, 201-218.

Jeppsson, L., Eriksson, M. E. \& Calner, M. 2005. Biostratigraphy of Gotland. In The Dynamic Silurian Earth: Subcommission on Silurian Stratigraphy Field Meeting 2005; Field Guide and Abstracts (Eriksson, M. E. \& Calner, M., eds), Sveriges geologiska undersökning. Rapporter och meddelanden, 121, 14-17.

Jeppsson, L., Eriksson, M. E. \& Calner, M. 2006. A latest Llandovery to latest Ludlow high-resolution biostratigraphy based on the Silurian of Gotland - a summary. GFF, 128, 109-114.

Jürgenson, E. 1988. Deposition of the Silurian Beds in the Baltic. Valgus Publishers, Tallinn, 176 pp. [in Russian, with English summary].

Kaljo, D. \& Martma, T. 2006. Application of carbon isotope stratigraphy to dating the Baltic Silurian rocks. $G F F, \mathbf{1 2 8}$, 123-129.

Kaljo, D. \& Nestor, H. (eds). 1990. Field Meeting Estonia 1990. An Excursion Guidebook. Institute of Geology, Estonian Academy of Sciences, IUGS subcommissions on Ordovician and Silurian and IGCP project "Global Bioevents", Tallinn, 210 pp.

Kaljo, D., Kiipli, T. \& Martma, T. 1994. Geochemical and isotope $\left(\delta^{13} \mathrm{C}\right)$ event markers through the Wenlock-Pridoli sequence in Ohesaare (Estonia). Erlanger Geologische Abhandlungen, 122, 23.

Kaljo, D., Kiipli, T. \& Martma, T. 1997. Carbon isotope event markers through the Wenlock-Pridoli sequence in Ohesaare (Estonia) and Priekule (Latvia). Palaeogeography, Palaeoclimatology, Palaeoecology, 132, 211-224.

Kaljo, D., Kiipli, T. \& Martma, T. 1998. Correlation of carbon isotope events and environmental cyclicity in the East Baltic
Silurian. In Silurian Cycles - Linkages of Dynamic Stratigraphy with Atmospheric, Oceanic and Tectonic Changes (Landing, E. \& Johnson, M. E., eds), New York State Museum Bulletin, 491, 297-312.

Kaljo, D., Martma, T., Grytsenko, V., Brazauskas, A. \& Kaminskas, D. 2012. Př́ídolí carbon isotope trend and upper Silurian to lowermost Devonian chemostratigraphy based on sections in Podolia (Ukraine) and the East Baltic area. Estonian Journal of Earth Sciences, 61, 162-180.

Kaljo, D., Einasto, R., Martma, T., Märss, T., Nestor, V. \& Viira, V. 2015. A bio-chemostratigraphical test of the synchroneity of biozones in the upper Silurian of Estonia and Latvia with some implications for practical stratigraphy. Estonian Journal of Earth Sciences, 64, 267-283.

Karatajūtè-Talimaa, V. \& Brazauskas, A. 1994. Distribution of vertebrates in the Silurian of Lithuania. Geologija (Vilnius), 17, 106-114.

Kiipli, T., Einasto, R., Kallaste, T., Nestor, V., Perens, H. \& Siir, S. 2011. Geochemistry and correlation of volcanic ash beds from the Rootsiküla Stage (Wenlock-Ludlow) in the eastern Baltic. Estonian Journal of Earth Sciences, 60, 207219.

Kozłowski, W. \& Sobień, K. 2012. Mid-Ludfordian coeval carbon isotope, natural gamma ray and magnetic susceptibility excursions in the Mielnik IG-1 borehole (Eastern Poland) dustiness as a possible link between global climate and the Silurian carbon isotope record. Palaeogeography, Palaeoclimatology, Palaeoecology, 339-341, 74-97.

Laufeld, S. 1974. Silurian Chitinozoa from Gotland. Fossils and Strata, 5, 1-130.

Loydell, D. K. 2012. Graptolite biozone correlation charts. Geological Magazine, 149, 124-132.

Männik, P. 2014. The Silurian System in Estonia. In 4th Annual Meeting of IGCP 591, Estonia, 10-19 June 2014; Abstracts and Field Guide (Bauert, H., Hints, O., Meidla, T. \& Männik, P., eds), pp. 123-128. University of Tartu.

Märss, T. 1986. Pozvonochnye silura Ếstonii i Zapadnoj Latvii [Silurian Vertebrates of Estonia and West Latvia]. Fossilia Baltica, 1, 1-104 [in Russian, with English summary].

Märss, T. 1992. Vertebrate history in the late Silurian. Proceedings of the Estonian Academy of Sciences, Geology, 41, 205-214.

Märss, T. 2001. Andreolepis (Actinopterygii) in the Upper Silurian of Northern Eurasia. Proceedings of the Estonian Academy of Sciences, Geology, 50, 174-189.

Märss, T. 2006. Thelodonts (Agnatha) from the basal beds of the Kuressaare Stage, Ludlow, Upper Silurian of Estonia. Proceedings of the Estonian Academy of Sciences, Geology, 55, 43-66.

Märss, T. 2019. Silurian cyathaspidid heterostracans of Northern Eurasia. Estonian Journal of Earth Sciences, 68, 113-146.

Märss, T. \& Männik, P. 2013. Revision of Silurian vertebrate zonation and correlation with conodont succession. Estonian Journal of Earth Sciences, 62, 181-204.

Märss, T., Afanassieva, O. \& Blom, H. 2014. Biodiversity of the Silurian osteostracans of the East Baltic. Earth and Environmental Science Transactions of the Royal Society of Edinburgh, 105, 73-148.

Martinsson, A. 1962. Ostracodes of the family Beyrichiidae from the Silurian of Gotland. Publication from the Palae- 
ontological Institution of the University of Uppsala, 41, 1369.

Martinsson, A. 1967. The succession and correlation of ostracode fauna in the Silurian of Gotland. Geologiska Föreningens i Stockholm Förhandlingar, 89, 350-386.

Martinsson, A. 1977. Baltoscandia. In The Silurian-Devonian Boundary (Martinsson, A., ed.), IUGS Series A, 5, 45-51.

Martma, T., Brazauskas, A., Kaljo, D., Kaminskas, D. \& Musteikis, P. 2005. The Wenlock-Ludlow carbon isotope trend in the Vidukle core, Lithuania, and its relations with oceanic events. Geological Quarterly, 49, 223-234.

Nestor, H. \& Einasto, R. 1977. Facies-sedimentary model of the Silurian Palaeobaltic pericontinental basin. In Facies and Fauna of the Baltic Silurian (Kaljo, D., ed.), pp. 89-121. Institute of Geology, Estonian Academy of Sciences, Tallinn [in Russian, with English summary].

Nestor, H. \& Einasto, R. 1997. Ordovician and Silurian carbonate sedimentation basin. In Geology and Mineral Resources of Estonia (Raukas, A. \& Teedumäe, A., eds), pp. 192-204. Estonian Academy Publishers, Tallinn.

Nestor, V. 1982. Correlation of the East-Baltic and Gotland Silurian by chitinozoans. In Ecostratigraphy of the East Baltic Silurian (Kaljo, D. \& Klaamann, E., eds), pp. 89-96. Valgus, Tallinn.

Nestor, V. 2007. Chitinozoans in the Wenlock-Ludlow boundary beds of the East Baltic. Estonian Journal of Earth Sciences, 56, 109-128.

Nestor, V. 2009. Biostratigraphy of the Ludlow chitinozoans from East Baltic drill cores. Estonian Journal of Earth Sciences, 58, 170-184.

Nestor, V. 2011. Chitinozoan biostratigraphy of the Pridoli Series of the East Baltic. Estonian Journal of Earth Sciences, 60, 191-206.

Nestor, V. 2012. A summary and revision of the East Baltic Silurian chitinozoan biozonation. Estonian Journal of Earth Sciences, 61, 242-260.

Paškevičius, J., Klimantavičius, V. \& Radzevičius, S. 2012. Lithostratigraphy, graptolites and brachiopods communities of the Ludlow (Silurian) of the Eastern slope of the Baltic Syneclise. Geologija (Vilnius), 54, 75-88.

Samtleben, C., Munnecke, A. \& Bickert, T. 2000. Development of facies and $\mathrm{C} / \mathrm{O}$-isotopes in transects through the Ludlow of Gotland: evidence for global and local influences on a shallow-marine environment. Facies, 43, 1-38.

Samtleben, C., Munnecke, A., Bickert, T. \& Pätzold, J. 2001. Shell succession, assemblage and species dependent effects on the $\mathrm{C} / \mathrm{O}$-isotopic composition of brachiopods - examples from the Silurian of Gotland. Chemical Geology, 175, 61107.

Sarv, L. 1968. Ostracode Families Craspedobolbinidae, Beyrichiidae and Primitiopsidae in the Silurian of Estonia. Valgus, Tallinn, 104 pp. [in Russian, with English summary].

Sarv, L. 1971. Silurijskie ostrakody v razreze skvazhiny Ohesaare [Silurian ostracodes in the Ohesaare boring]. Eesti NSV Teaduste Akadeemia Toimetised, Keemia, Geoloogia, 20, 349-355 [in Russian, with English summary].

Sarv, L. 1977. Early cavellinids in the Silurian of the East Baltic. In Facies and Fauna of the Baltic Silurian (Kaljo, D., ed.), pp. 259-283. Institute of Geology, Estonian Academy of Sciences, Tallinn [in Russian, with English summary].

Spiridonov, A., Stankevič, R., Gečas, T., Šilinskas, T., Brazauskas, A., Meidla, T., Ainsaar, L., Musteikis, P. \& Radzevičius, S. 2017. Integrated record of Ludlow (upper Silurian) oceanic geobioevents - Coordination of changes in conodont, and brachiopod faunas, and stable isotopes. Gondwana Research, 51(11), 272-288.

Urbanek, A. 1997. Late Ludfordian and early Pridoli monograptids from the Polish Lowland. Palaeontologia Polonica, 56, 87-231.

Urbanek, A. \& Teller, L. 1997. Graptolites and stratigraphy of the Wenlock and Ludlow Series in the East European Platform. Palaeontologia Polonica, 56, 23-57.

Verniers, J., Nestor, V., Paris, F., Dufka, P., Sutherland, S. \& Van Grootel, G. 1995. A global Chitinozoa biozonation for the Silurian. Geological Magazine, 132, 651-666.

Viira, V. 1982. Late Silurian shallow and deep water conodonts of the East Baltic. In Ecostratigraphy of the East Baltic Silurian (Kaljo, D. \& Klaamann, E., eds), pp. 79-88. Valgus, Tallinn.

Viira, V. 1999. Late Silurian conodont biostratigraphy in the northern East Baltic. Bollettino Societa Paleontologica Italiana, 37, 299-310.

Viira, V. \& Aldridge, R. J. 1998. Upper Wenlock to Lower Prridoli (Silurian) conodont biostratigraphy of Saaremaa, Estonia, and a correlation with Britain. Journal of Micropalaeontology, 17, 33-50.

Viira, V. \& Einasto, R. 2003. Wenlock-Ludlow boundary beds and conodonts of Saaremaa Island, Estonia. Proceedings of the Estonian Academy of Sciences, Geology, 52, 213238.

Younes, H., Calner, M. \& Lehnert, O. 2017. The first continuous $\delta^{13} \mathrm{C}$ record across the Late Silurian Lau Event on Gotland, Sweden. GFF, 139, 63-69.

\title{
Kesk-Ludfordi süsiniku isotoopanomaalia taseme otsing Ohesaare puursüdamikus bio- ja kemostratigraafiliste tunnuste alusel
}

\author{
Dimitri Kaljo, Tõnu Martma, Tiiu Märss, Viiu-Kai Nestor ja Viive Viira
}

Ohesaare puursüdamiku läbilõige ja kivististe kooslused on aastaid inspireerinud uurijaid uute ideede arendamisel Siluri stratigraafia alal. Läbilõige koosneb valdavalt madalmere kivimitest tavapäraselt sagedate settelünkadega. Nendest üks langeb kokku Kesk-Ludfordi süsiniku isotoopanomaalia (ingl. akronüüm MLCIE) tasemega, mistõttu ei olnud võimalik selle asukohta analüütiliselt määrata. MLCIE kajastab Paleosoikumi suurimat isotoopgeoloogilist sündmust, millel on 
suur kasutusväärtus kronostratigraafias ja erinevate paleokeskkonda mõjutavate protsesside (näiteks Lau okeanoloogiline sündmus) uurimisel. Nii sai meie artikli ülesandeks leida nelja fossiilirühma (kitiinikud, konodondid, ostrakoodid ja vertebraadid) biostratigraafilise leviku ja biomitmekesisuse analüüsi abil MLCIE asukoht Ohesaare läbilõikes. Vajaliku detailsuse tagamiseks jagasime Paadla lademe Torgu kihistu viieks lõiguks, milles uurisime fossiilide levikumustrite muutusi ja võrdlesime neid andmetega naaberaladelt (Gotlandi paljandid, Ventspilsi puursüdamik), ning mõne parameetri osas ka Leedust ja Poolast. Kokkuvõttes leidsime otsitava katkestuspinna, mis tõenäoliselt varjab endas ligikaudu pool miljonit aastat geoloogilist ajalugu, Torgu kihistu ülemisest osast. 